\title{
The Relation between Olympians and Employees of the Media in Hungary: Motivations, Attitudes, Rejection
}
Authors' contribution:
A) conception and design of the study
B) acquisition of data
C) analysis and interpretation of data
D) manuscript preparation
E) obtaining funding

\author{
Agnes Kovacs ${ }^{\text {A-E }}$, Tamas Doczi ${ }^{\mathrm{A}, \mathrm{C}, \mathrm{D}}$ \\ University of Physical Education, Budapest, Hungary
}

ABSTRACT

In the present study, we examine the relation between Olympians and employees of the media in Hungary through the following terms: motivations, attitudes, and rejection. The empirical research presented in this paper focused on the following research questions:

1.What motivates Olympians and employees of the media in their cooperation?

2. What kind of attitudes characterise them in their relation?

3. Why and how often do employees of the media get rejected by elite athletes?

In the framework of the research, a survey was carried out among the Hungarian Olympic athletes participating at the Rio 2016 Olympic Games $(\mathrm{N}=104)$ and on the total population of media workers accredited to the Olympics $(\mathrm{N}=28)$. The data were collected by two questionnaires. The first one contained 31 questions for the Olympians, and the second one had 26 questions for the media workers. The two versions included overlapping sections as well, which made it possible to explore the respondents' views on the same topic and get comparable outcomes in some cases. The analysis aims to present and contrast the viewpoints of Olympians and employees of the media with each other. The results show that over half of elite athletes do not like to participate in the media, but they are aware that it is necessary; that is the reason why many of them mostly accept sport related interview requests. Parallel with this, media workers assume that the majority of elite athletes like to appear in front of the public. In general terms, the main goals for elite athletes are to train well, to qualify for major international meets, and to achieve outstanding results. On the other side, the intentions of the media workers is to publish stories to the audience, which could be positive, negative, informative, provocative, or sensational. Elite athletes and employees of the media need to be more aware of each other's motivations, attitudes and aims for better understanding each other.

KEYWORDS

\section{Introduction}

Technological changes opened worldwide access to endless news and information, which caused the mass media to become a strong cultural source of information, and also a powerful entertainer device (Sage, 2010). In the last decades, the transformation of the media, globalization, and also all technological changes have all had an enormous impact on the social subsystem of sport. 
"At one level globalization has driven and accelerated changes in the relationship between sport and the media, while at another level sport and its media partners have played an important role in the globalizing process" (Nicholson, et al. 2015, p.14).

New technologies increased the field and range of communication, consequently information is available indefinitely (Silverstone, 2008). Sport is a determined social subsystem; therefore, it is an increasingly affected area of these changes.

"Media sport has the perfect combination for communicating entertainment, including controlled violence, excitement, and lots of audio and visual power" (Sage 2010, p. 150).

In this revolutionary process, elite athletes are dominantly involved individuals in sport sections. They are the people who are in front of the public, and many of them are well known, because of their achieved results, but also because of other influential factors. What media covers about sport and elite athletes is significant, because media representation could define the perception of the public (Földesiné et al. 2010).

Along with the process of globalization various things have changed in the relation of elite athletes and the employees of the media. This shift is mostly affected by the emergence of consumer society and tabloidization. In this new era, when tabloid news is getting more and more publicity, the way of journalism has changed in a remarkable way (Kovács \& Dóczi 2015). Oftentimes, sensational, unusual and strange happenings are published for attracting the attention of readers and viewers. This type of journalism is also becoming prevalent in other social subsystems; however, in sport, being an important area of popular culture, this shift is even more apparent.

One outcome of these processes is that by now, according to Billings et al. (2015), today's great sports heroes do not only display their greatness on the field, but they also have a number of positive personal characteristics. This raises numerous questions, for example: What is the main goal for an athlete? What is the most important objective for someone who works in the media? Do the two parties have similar motivations in their relation, or their aims in terms of their "job" are totally different. In general terms, the main goals for elite athletes are to train well, to qualify for major international meets, and to achieve outstanding results. Parallel with this process, the intentions of the media workers is to publish stories to the audience, which could be positive, negative, informative, provocative, or sensational. Misunderstanding between athletes and reporters could cause conflict in the relation (Shultz \& Arke 2016).

The quality of the relation of elite athletes and employees of the media may have strong impact on motivations, attitudes, or even on incidents of rejection towards each other.

"In some cases, the reporter-athlete relationship becomes adversarial. Typically, this is determined by the athlete, who has decided that he can no longer trust the media, has been burned by too many critical comments or simply doesn't want to talk" (Shultz \& Arke 2016, p.78).

Because of this issue, employees of the media are responsible for what is published. However, athletes also need to accept and understand, the truth is not always on their side, and journalists do not intentionally become their enemies in these cases. Nevertheless, the technological revolution does not always imply an improvement in quality: in most of the case the news is urged to be published as soon as possible, and nowadays in most of the cases the required goal for the media workers is to attract attention. In many cases profitability is more important than quality (Kovach \& Rosenstiel 2014).

The reason for cooperation between the sport and the media sector is that sport is one of the most interesting topics for the public; and at the same time, the biggest sport competitions, like the Olympic Games, have become global because of the media (Gál 2007). The tabloid press, in a global sense, has existed for more than 20 years in Hungary. Because of the dominant media attention around Olympic athletes, the tabloid media has become hardly avoidable, which could cause uncertainty for elite athletes related to the kinds of topics they should appear in the media. In Hungary, Olympians' preparation is mostly subsidized by the state; however, in many cases sponsors also help to finance the preparation of elite athletes. The support by the state is based on previous sport achievements; therefore in most of the cases the athletes' media representation does not affect their basic preparation needs; however, extra help from sponsors could always be helpful, and for this, a strong media presence is required. 
The media does not just reflect, but also form the views of the public. The mediatized reality and the emergent mass culture establish norms, which show the way to the audience how to evaluate values and actions (Gálik \& Urbán 2014). Because of the media's opinion shaping power it is very important what kind of norms and values are transmitted in the news in connection with sport in general and with an elite athlete in particular. By now, we have reached a situation when although elite athletes may have issues with participation in the media, they are not in a position anymore to completely avoid it if they want to. Regardless of personal characteristics or previous experiences, the relationship between elite athletes and journalists has become one that both sides are obliged to maintain.

Taking this 'must' into consideration, the objective of this study is to examine the relation between Olympians and employees of the media in Hungary through the following terms: motivations, attitudes, and rejection. The empirical research presented in this paper focused on the following research questions:

1. What motivates Olympians and employees of the media in their cooperation?

2. What kinds of attitudes characterize them in their relation?

3. Why and how often do employees of the media get rejection from Olympians, which may cause conflict?

\section{Methods}

\section{Participants of the research}

The research was granted permission from the Hungarian Olympic Committee, which allowed us to send the questionnaires to each athlete who had qualified for the Rio 2016 Games, and each media worker accredited to the event by the HOC.

At the 2016 Summer Olympic Games altogether 160 (67 female and 93 male) Hungarian athletes competed in 22 different sports. Overall 104 athletes answered the questions out of the total population, representing 20 sports (with the exception of table tennis and badminton): kayak-canoe, athletics, wrestling, rowing, mountain biking, judo, diving, boxing, modern pentathlon, shooting, weightlifting, windsurfing, taekwondo, tennis, gymnastics, triathlon, swimming, sailing, fencing and water polo. The average time of their elite sport career was 18.57, with a minimum of 7 and a maximum of 36 years. On average, they have been members of the national team for 8.01 years, with 12 first-year members and three athletes with over 20 years of international experience.

A total number of 28 media employees got accreditation to the 2016 Games from the Hungarian Olympic Committee, representing 22 different types of press, as: public, commercial and sport media, and all of them took the time to answer our questions.

All in all, the complex final return rate of the surveys was $82 \%$ from the two groups. $65 \%$ of the Hungarian Olympic athletes $(\mathrm{N}=104)$, and $100 \%$ of the accredited media workers $(\mathrm{N}=28)$ returned the questionnaire. Table 1 displays the characteristics of the responding Olympic athletes, and how they correspond to the characteristics of the total population in terms of gender and age.

Table 1. Characteristics of the examined and the total population (elite athletes)

\begin{tabular}{|c|c|c|c|c|c|}
\hline \multirow{3}{*}{ Gender } & & \multirow{2}{*}{\multicolumn{2}{|c|}{$\begin{array}{c}\text { Examined population } \\
\mathrm{N}=104\end{array}$}} & \multirow{2}{*}{\multicolumn{2}{|c|}{$\begin{array}{c}\text { Total population } \\
\mathrm{N}=160\end{array}$}} \\
\hline & & & & & \\
\hline & & $\mathrm{N}$ & $\%$ & $\mathrm{~N}$ & $\%$ \\
\hline & Male & 63 & 60.6 & 93 & 58.1 \\
\hline & Female & 41 & 39.4 & 67 & 41.9 \\
\hline \multicolumn{6}{|l|}{ Age } \\
\hline & $14-20$ & 16 & 15.4 & 21 & 13.1 \\
\hline & $21-26$ & 33 & 31.7 & 61 & 38.1 \\
\hline & $27-32$ & 40 & 38.5 & 61 & 38.1 \\
\hline 33 or more & & 15 & 14.4 & 17 & 10.7 \\
\hline
\end{tabular}

Source: Own study. 


\section{Data collection and processing}

The data from the athletes were collected by an online questionnaire, which was conducted from 15.05.2016 to 31.08.2016. An email with a cover letter and with a link to the survey was sent to the Hungarian Olympians of 2016, asking them to answer to the questions. The 104 Olympians filled out the online survey within the aforementioned period.

With regards to the journalists, 22 of them responded to the survey during an orientation before the Olympics, which was held at the Hungarian Olympic Committee on 25.05.2016. Accredited media workers who did not participate at the orientation - 6 of them - filled the online survey, between 25.05.2016 and 10.06.2016.

The questionnaire contained 31 questions for the Olympians, and 26 questions for the media workers. Among the questions there were different ones, but overlapping sections as well, which made it possible to explore the respondents' views on the same topic and get comparable outcomes in some cases.

The statistics were measured using the SPSS statistics program. The value for statistical significance is .05. The results were analysed by descriptive statistics, Chi-Square tests, and Symmetric measures. The data were evaluated separately and also compared with each other, with regards to the two examined groups Olympians and media workers.

\section{Results}

In the following section, the results are to be introduced according the dimensions identified by the research objectives: motivations, attitudes and rejection. In the first, most extensive part, the general motivational patterns of Olympic athletes related to media appearance are to be presented and contrasted with how the journalists see the athletes' willingness to participate. The next section reflects on how the two parties see one another in terms of certain personal characteristics, mainly related to trust. The final section of the results is then devoted to the reasons why athletes tend to reject some media requests.

\section{Motivations}

If we want to understand the relation between elite athletes and media workers, the first issue to be discussed is what motivates athletes to participate in the media and how much they are willing to accept it as necessary. The opinions of Olympic athletes and media workers significantly differ in relation to the competitors' willingness to appear in the media. Over half of the athletes claimed they do not like to appear in the media, whereas only 25 percent of journalists assumed negative attitudes for the same subject on the part of athletes (Table 2.).

Table 2. Athletes' attitudes to appearance in the media according to themselves and the media workers $\left(\chi^{2}=21,502 ; \mathrm{df}=3 ; \mathrm{p} \leq 0.001\right)$

\begin{tabular}{lc|ccccc}
$\begin{array}{l}\text { lno you / Do } \\
\text { athletes like to be } \\
\text { in the media? }\end{array}$ & Not at all & $\begin{array}{c}\text { Not really, but I } \\
\text { know sometimes it } \\
\text { is necessary }\end{array}$ & $\begin{array}{c}\text { Yes, but mostly in } \\
\text { sport related topics }\end{array}$ & $\begin{array}{c}\text { Yes, almost in } \\
\text { every topic }\end{array}$ & Total \\
\hline $\begin{array}{l}\text { Olympic } \\
\text { athlete }\end{array}$ & $\mathrm{N}$ & 2 & 56 & 23 & 23 & 104 \\
\hline Media & $\mathrm{N}$ & $1.9 \%$ & $53.8 \%$ & $22.1 \%$ & $22.1 \%$ & $100.0 \%$ \\
worker & $\%$ & $0.0 \%$ & $25.0 \%$ & 19 & 2 & 28 \\
\hline \multirow{2}{*}{ Total } & $\mathrm{N}$ & 2 & 63 & $67.9 \%$ & $7.1 \%$ & $100.0 \%$ \\
\hline
\end{tabular}

Source: Own study

Athletes over 30 years of age are more open to the media workers, than the younger generation, perhaps because they have more experience in the world of the press. If we measure the topic of media appearance related to the athletes, male competitors are slightly more open to questions which are not about sport related topics. However, the majority of athletes $(53.8 \%$ ) are not in favour, but still accept it as necessary, while media workers claimed most athletes (67.9\%) like to be in the media, at least in sport related topics. 
Elite athletes' main motivation to be in the media is to represent their sport and the least pulling power is that they actually like to participate in front of the public (Table 3).

Table 3. Motivations of athletes to be in the media

\begin{tabular}{l|l|l} 
Answer & Mean & ST.D. \\
\hline To represent my sport & 3.57 & 0.721 \\
\hline $\begin{array}{l}\text { As an elite athlete I am obligated to } \\
\text { accept those requests }\end{array}$ & 3.31 & 0.758 \\
\hline To show an example & 3.30 & 0.861 \\
\hline Someone asks me to do it & 3.03 & .954 \\
\hline Because of sponsors & 2.94 & .958 \\
\hline Could be useful for the future & 2.86 & .940 \\
\hline Because of fame & 2.38 & 1.077 \\
\hline I like to be in the media & 1.68 & .806 \\
\hline Source: Own study. & \\
\hline
\end{tabular}

Source: Own study.

Olympians also think that being a role model is an obligation for them to accept the requests of the media workers. They tend to respond to requests on a situational basis, but on the other hand, more strategic, longterm goals seem to be less important in their decision to contribute.

Males' motivations are significantly higher $(\mathrm{p} \leq 0.05)$ for fame and future, and younger ones are more inspired $(\mathrm{p} \leq 0.05)$ by future perspectives.

The results in Table 4 show that the two parties' opinion is very similar about the main topics in connection which elite athletes are keen on participating in the media, that is: competition and performance related topics. The assumption is also comparable in a positive way in terms of charity and other sport related issues. During our examination we can observe a significant difference in connection with positive news. Elite athletes are less likely to appear in the media than the media workers would assume in this topic.

Table 4. Elite athletes' preferences in what topics to appear in the media in the views of themselves and the media workers

\begin{tabular}{l|c|c|c} 
& \multicolumn{2}{c}{ Opinion of Olympic athletes } & \multicolumn{2}{c}{ Opinion of media workers } \\
\hline Answer & Mean & STD & Mean \\
\hline Competition, results & 3.75 & .535 & 3.93 \\
\hline Charity & 2.94 & 1.056 & 3.18 \\
\hline Other sport related topics (Training, sponsor,...) & 2.78 & .986 & 3.04 \\
\hline Current positive news*** & 2.45 & 1.245 & 3.75 \\
\hline Civil life ( hobby, cooking, traveling,...) & 2.23 & 1.081 & .881 \\
\hline To offer an opinion about something & 1.78 & .945 & .934 \\
\hline $\begin{array}{l}\text { Other public appearances ( TV show, quiz } \\
\text { program,...) }\end{array}$ & 1.76 & .907 & 2.11 \\
\hline
\end{tabular}




\begin{tabular}{l|c|c|c|c} 
Current negative news & 1.62 & .938 & 1.64 & 1.096 \\
\hline Private life (relationship, family,...) & 1.58 & .823 & 1.68 & 1.090
\end{tabular}

Source: Own study.

In some aspects we could observe significant differences, namely in connection with "current positive news" $\left(\chi^{2}=24,895 ; \mathrm{df}=3 ; \mathrm{p} \leq 0.001\right)$, and in the case of other public appearances, which are not related to sport $\left(\chi^{2}=10,47 ; \mathrm{df}=3 ; \mathrm{p} \leq 0.05\right)$. The former can also be attributed to the fact that the label, which is widely used in media circles could be much less clear for the Olympians; however, the difference in how the two parties perceive TV show appearances further underlines the previously presented data.

\section{Attitudes}

Although the motivations of athletes and journalists may differ in relation to media appearances, the question of how the two parties perceive the other in certain characteristics and how much they trust one another is a different aspect, which may also have an influence on athletes' decision whether to accept a request by the media. When investigating the opinions of the two parties related to one another on a personal level (Table 4), it can be remarked that there are no statistically significant differences. Generally, the Other is seen as cooperative and confident. Based on the results, it can be marked that, cooperation and empathy are strong in both cases. Olympians think media workers are moderately honest, while the other party's opinion is higher in this case.

With regards to negative characteristics, according to the athletes, media workers are extremely (3.22) seeking for sensations, and are moderately provocative (2.71). Employees of the media say that elite athletes tend to be careful (3.18), and untrustworthiness (1.70) is not characteristic of them.

Table 5. General opinion of Olympic athletes and employees of the media about each other

\begin{tabular}{l|c|c|c|c} 
& \multicolumn{2}{|c}{ Opinion of Olympic athletes } & \multicolumn{2}{c}{ Opinion of media workers } \\
\hline Answer & mean & st.dev. & Mean & st.dev. \\
\hline Cooperative & 3.02 & .660 & 2.96 & .576 \\
\hline Self-confident & 2.96 & .696 & 3.18 & .612 \\
\hline Tolerant & 2.66 & .691 & 2.96 & .576 \\
\hline Sympathetic & 2.55 & .737 & 2.64 & .621 \\
\hline Superficial & 2.54 & .709 & 2.11 & .786 \\
\hline Sincere & 2.44 & .786 & 2.89 & .577
\end{tabular}

Source: Own study.

\section{Rejection}

In order to gain a better understanding of why Olympic athletes are reluctant to accept certain media requests, we investigated their past (perhaps negative) experience in the field. $64 \%$ of the athletes could recall that something was published that they did not like and almost $40 \%$ of them said they rejected an interview because of negative experiences from the past. From the media workers' side, 57\% said they never had any conflicts with the athletes and just $25 \%$ of them had the experience of rejection because of an athlete's previous negative experience. If we compare these numbers we can see that $15 \%$ of the athletes find another excuse not to accept an interview instead of mentioning the real reason for the rejection. 
$85 \%$ of elite athletes mostly accept the interview requests related to topics of competition and results, however almost $50 \%$ of them reject all private life request. The vast majority of media workers (92\%) experience that competitors usually give interviews about competition-related topics and almost $30 \%$ of athletes never talk to them about their private life.

\section{Discussion}

Sport and media could exist without each other, however if they use each other's strengths they could be more successful individually as well (Coakley, 2015). Media can magnify the horizon of our world outlook, but it also can control and monitor our impressions (Gálik \& Urbán, 2014). In the present study we demonstrated the views of Olympians and employees of the media in terms of: motivations, attitudes and rejection. During our research we could observe that the two parties have many commonalities and we also found some significant differences in their viewpoints.

"Many times interests and values from the journalist's perspective can be different than in the athletes' view. From a media worker's standpoint to publish story is always important, even if it is bad for the athletes" (Kovács, 2016, p. 284).

The results show that despite many similarities, the standpoints of Olympians and media workers differ in many aspects, which could cause misunderstanding in their relations. Based on the results media workers are aware in what topics elite athletes usually do and do not like to participate in front of the public; however the research data show media workers assume more openness from elite athletes compared to how much this is true in reality. The majority of elite athletes do not like to appear in front of the public, but as sportspeople they feel obligation for media appearance and that is one of the most important reasons why they still accept an interview request. Based on our research results, in many cases, Olympians reject an interview request because of their lack of time, while other dominant causes for rejection could be lack of trust, the topic of the request, general fears or other trivial issues. Everybody would like to do their work; however, in certain cases, the lack of information could cause a lack of communication and ultimately, rejection. In most of the cases the openness is given from both sides, and they generally attach positive personal characteristics to the Other, but in many cases the journalists are not well-informed about the athletes, which is obviously perceived as dereliction. Nevertheless, positive examples also exist: it is typically well received by athletes when a journalist has been dealing with their sport for a longer time, as it allows for a more trustful relationship to evolve.

The research results show that attitudes towards each other are positive in most of the cases, yet motivations and aims could be similar or different in relation to many issues between elite athletes and media workers. Differing motivations may especially become problematic when athletes are engaged in preparation and would like to focus on their sport rather than talk about it, and also when the results of the competition were not favourable for them, but journalists would still like to do their job, even if this means negative news about the athletes. We found that the general perception is decent for both parties; however, a better understanding of each other could be a step towards improved relations.

\section{Conclusion}

"Globalization is the term used to explain the easy travel and 24/7 communication connectivity" (Etang, 2013, p. 70.). The new digital communication forms could influence our daily life and determine our relationship with others (Szécsi, 2016). Media has changed tremendously in the last couple of decade and sport as a social subsystem has been remarkably influenced in this process. Elite athletes will always be in the media, and as role models, in most of the cases they are aware of the responsibility of being in front of the public.

In the case of elite athletes to train well and to achieve good results is the key objective. However, their awareness of the importance of the media appearance is a crucial issue. Elite athletes and employees of the media need to be more aware of each other's attitudes, motivations and aims for a better understanding of one another.

Setting up certain rules could be helpful for both parties; for example, a "guide", which would give a hand how to manage the nexus between them. With a planned structured itinerary which would give information about what time of the year the athlete is available for what kind of media appearance, or when 
and what are the important competitions in the year - the outcome could be more satisfaction and less rejection on both sides. This could also be supported by clarifying the rights and obligations for the two parties.

The results of the paper highlight the main motivations and attitudes, and the causes of rejection between Olympic athletes and employees of media, and this may open directions for further research. One of these could be a survey among elite athletes and media workers, which would focus on elite athletes' social media appearances, an area that has become increasingly influential in their communication. This new type of research could demonstrate how much and how the new media can affect the nexus between the two parties.

\section{REFERENCES:}

Billings, A.C., Butterworth, M.L. \& Turman, P.D. (2015). Communication and Sport. Thousand Oaks: SAGE.

Brad, S \& Ed A. (2016). Sports Media. New York: Focal Press.

Coakley, J. (2015.): Sports in Society: Issues and Controversies. New York: McGraw-Hill.

Földesiné, S.G., Gál A. \& Dóczi, T. (2010). Sportszociológia /Sociology of Sport/. Budapest: Semmelweis Egyetem Testnevelési és Sporttudományi Kar.

Gál, A. (2007). Sport és társadalmi nem a 21. század elején a média tükrében Magyarországon /Sport and gender in the mirror of the media in Hungary at beginning of the $21^{\text {st }}$ century/. $\mathrm{PhD}$ thesis, Budapest: Semmelweis University.

Gálik, M. \& Urbán, Á. (2014). Médiagazdaságtan /Studies in Media Economy/. Budapest: Akadémiai Kiadó.

George, H.S. (2010). Globalizing Sport. Boulder: Paradigm Publisher.

Jacquie, L.E. (2013). Sports Public Relations. London: Sage.

Kovács, Á. (2016) View of Elite Athletes and Employees of the Media in Hungary: Values, Interests and Conflicts. Sport and social sciences with reflection on practice. Warsaw: AWF, 279-288.

Kovács, Á. \& Dóczi, T. (2015). A sportmédia változásai az 1990-es évektől napjainkig: a media szerepének, és a globalizáció hatásának bemutatása az élsportolók és a média kapcsolatában /The shift of sport media from 1990s' until nowadays: introduction of the role of media and the effect of globalization in the relation of elite athletes and employees of the media/. Magyar Sporttudományi Szemle 63(3), 35-42.

Kovach, B. \& Rosenstiel, T. (2014). The elements of journalism. New York: Three River Press.

Nicholson, M., Kerr, A. \& Sherwood, M. (2015). Sport and the Media, Managing the nexus. Oxon: Routledge.

Shultz, B. \& Arke E. (2016). Sports Media: Reporting, Producing and Planning. New York: Routledge.

Silverstone, R. (2008). Media and Morality. On the Rise of the Mediapolis. Cambridge: Polity Press.

Szécsi, G. (2016). Média és társadalom az információ korában /Media and society in the era of information/. Budapest: Akadémiai Kiadó.

AUTHOR'S ADDRESS: $\quad$ Agnes Kovacs University of Physical Education, Budapest

International Relations

Alkotas street 44

1123 Budapest, Hungary

E-mail: kovacs.agnes@tf.hu

Received: 24 February 2018; Accepted: 15 April 2018 